DOI: https://doi.org/10.31933/dijemss.v2i2

Received: $27^{\text {th }}$ September 2020, Revised: $15^{\text {th }}$ November 2020, Publish: $3^{\text {rd }}$ December 2020

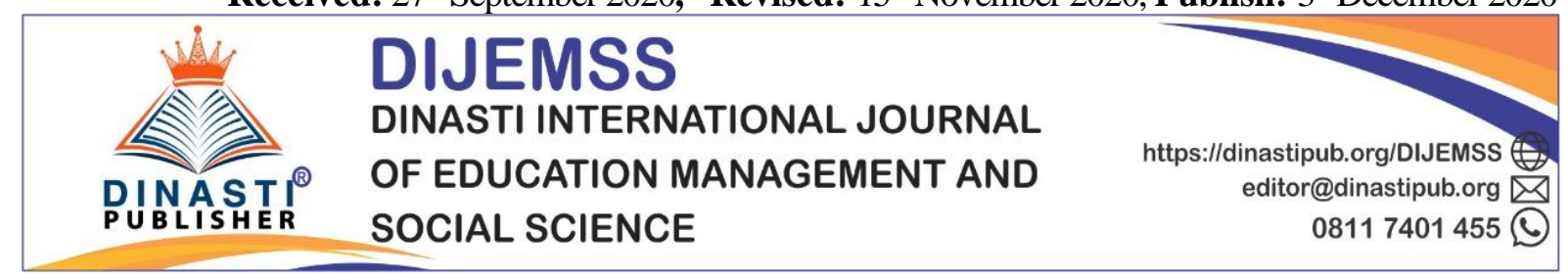

\title{
DETERMINANTS OF EMPLOYEE PERFORMANCE IN PT. PERTAMINA (PERSERO)
}

\section{Eka Candra Dinata ${ }^{1}$, Dessy Adelin ${ }^{2}$}

${ }^{1}$ PT. Pertamina, Indonesia, eka.dinata@pertamina.com

${ }^{2}$ Institusi IKPIA Perbanas Jakarta, Indonesia. dessy.adelin@perbanas.id

\section{Corresponding Author: First Author}

Abstract: The purpose of this study was to determine and analyze: (1) Workload (2) Competence; (3) Performance Officer; and (4) The Effect of Workload and Competence on Employee Performance in the Production Department of PT. Pertamina either simultaneously or partially. The method used in this research is descriptive survey and explanatory survey, the unit of analysis in this study is employees in the Production Department of PT. Pertamina with a sample of 33 people. The type of investigation used is causality, and the time horizon in this study is cross-sectional. Based on the research results it was found that the workload experienced by the Production Department of PT. Pertamina is good, employee competence in the Production Department of PT. Pertamina in general can be said to be quite good. Employee Performance in the Production Department of PT. Pertamina is currently considered good. Workload and Competence affect the performance of employees in the Production Department of PT. Pertamina simultaneously and partially. However, partially Competence has a dominant effect on Employee Performance compared to Workload. Because Competency Performance is more dominant, it is prioritized in improving performance. Therefore the Production Department of PT. Pertamina is advised to increase the potential competencies that exist in each employee, so that they can work more professionally. Employee Performance at the Production Department of PT. Pertamina is currently considered good. Workload and Competence affect the performance of employees in the Production Department of PT. Pertamina simultaneously and partially. However, partially Competence has a dominant effect on Employee Performance compared to Workload. Because Competency Performance is more dominant, it is prioritized in improving performance.

Keywords: Workload, Competence, Performance

\section{INTRODUCTION}

Superior human resources are one of the main requirements for the realization of a developed nation. Apart from natural resources (as above), the capital of the available facilities and infrastructure is ultimately in the hands of one tablespoon that can be relied on, the development targets of the state and nation can be achieved. Thinking like this in perspective, a nation cannot achieve progress without a good service system. 
According to uterus and rashid (2001) in othman and suhid (2010: 118) that all parties need to play a full role in overcoming the problem of service to the community, not only field officers who are partially serving. but high-ranking officials who have the same duty in terms of providing services. This opinion shows the important role of the state civil apparatus (employees) in the world of government. Employee performance has an important role in achieving organizational goals. Performance issues will be under the spotlight of various parties, government performance will be perceived by the public and employee performance will be perceived by the public. efforts have been made to achieve good performance. government attention has been socialized services. then employee performance is of course the concern of all parties. employees must be truly competent in their fields and employees must also be able to serve optimally. Optimal employee performance is influenced by various factors, both internal and external.

Furthermore, based on research conducted by HAUCK et al. (2008) argued that the accumulation of workloads will result in decreased performance and increased work stress. Similar results are also shown in research conducted by Lisnayetti and Hasan Basri (2006) who found that workload is related to professor performance, high-performance workload is less.

From this description, it is not optimal for the employees' performance at the Production Department of PT. Pertamina allegedly felt that the workload of employees was too heavy. This is reinforced by the following research findings:

1. Lack of coordination between employees in various parts, resulting in information asymmetry.

2. Inadequate facilities and infrastructure, especially technical support in administrative management.

3. Increasing demands for the quality of work make employees bored and bored in doing their daily work

4. The time limit for the implementation of tasks tends to be tight, making it difficult for employees to complete the task concerned

\section{LITERATURE REVIEW}

Human Resource Management

According to Cascio (2003: 10), "Human resource management is an art and science

that regulates the relationships and roles of the workforce in order to efficiently and effectively help form organizations, employees, and society". Human resource management is the science and art that regulates the relationships and roles of the workforce to be efficient and effective in helping the realization of organizational, employee and community goals. 
The notion of resource management in humans is an art and science that studies how to manage human resources efficiently by carrying out human resource management functions optimally to achieve individual and organizational goals.

According to Siagian (2008: 21), the functions of human resource management are as follows: (a) planning, (b) Organizing, (c) Direction, (d) Control, (e) Procurement, (f) Development, ( g) Compensation, (h) Integration, (i) Maintenance, (j) Discipline, (k) Termination.

\section{Workload}

The definition of workload is a set or several activities that must be completed by the incumbent organizational unit or within a certain period of time. Measurement of workload is defined as a technique for obtaining information about the efficiency and effectiveness of an organizational unit, or incumbent which is carried out systematically using job analysis techniques, workload analysis techniques or other management techniques. Furthermore, it was also stated that measurement is one of the workload management techniques to obtain office information, through the research and review process analysis is carried out. Office information is intended to be used as a basis for improving institutional apparatus, procedures, and human resources (ministers,

Everly et al (in Munandar, 2001) say that workload is a situation where workers are faced with tasks that must be completed at a certain time. Another workload category is a combination of quantitative and qualitative workloads. Quantitative workloads that arise from too many or few tasks, while qualitative workloads if workers feel unable to carry out a task or task do not use the skills or potential of the worker.

Clarification Workload

a) Quantitative overload, 
Excessive physical and mental load due to too much activity is a source of work stress.

b) Too little quantitative load,

Too little quantitative workload can also affect a person's psychological well-being.

c) Qualitative overload

Technological advances have resulted in most of the work that was previously done manually by humans / labor being taken over by machines or robots so that human work shifts the emphasis on brain work.

d) Too little qualitative burden

Too little qualitative load is a situation in which the workforce is not allowed to use the acquired skills, or develop the full potential of skills.

\section{Factors Affecting Workload}

Rodahl (1989) and Manuaba (2000) in Prihatini (2007), state that workload is influenced by the following factors:

External factors are loads that come from outside the worker's body, such as:

a. The task is done physically

b. Work organization

c. Work environment

These three aspects are called stress extortionists.

Internal factors are factors that come from within the body as a result of reactions to outside workloads. The reaction of the body is called a stretch, the severity of the strain can be assessed both objectively and subjectively. Internal factors include somatic factors (gender, age, body size, nutritional status, health condition), psychological factors (motivation, perception, belief, desire, and satisfaction). 


\section{Impact Workload}

Excessive workload will cause both mental and physical fatigue as well as emotional reactions such as headaches, indigestion, and irritability. While the workload is too little where the work occurs because of the reduction in motion, it will cause a feeling of boredom and a sense of monotony. Boredom in the routine of daily work for tasks or jobs that are too little results in a lack of attention to work so that it is potentially dangerous for workers (Manuaba, 2000, in Prihatini, 2007).

\section{Competence}

Ariffin and Zailani (2011: 189) state that "competence is defined as the characteristics of an employee that contribute to the success of work performance and the achievement of organizational results". Competence which is a characteristic of employees who have a role in improving performance and achieving organizational goals. Ariffin and Zailani also emphasized that competence "includes knowledge, skills and abilities plus other characteristics such as values, motivation, and initiative and self-control". Competence which includes knowledge, skills and abilities coupled with other characteristics, such as values, motivation, and initiative, as well as self-control.

In relation to the strategic role of human resources, competence is carried out with an organizational understanding of the role of human resource problems that were originally human to become business problems related to people.

Performance

According to Sedamayanti (2004: 176), "performance is the result of work that can be achieved by individuals or groups of people in an organism in accordance with their respective powers and responsibilities in achieving organizational goals legally, not violating laws and morals. and ethical ". 
Furthermore, Mangkunagara (2005: 67) defines performance as follows: "Performance is the result of the quality and quantity of work performed by an employee in carrying out his duties in accordance with the responsibilities assigned to him".

Based on some of the above definitions, it can be concluded that performance is the work result (output and outcome) of employees both in quantity and quality in an organization according to the responsibilities and types of work assigned to them.

Factors Affecting Performance

According to Cummings and Schwab (1973), Porter and Lawler (1968), Vroom (1960) in Sumantri (2001: 63), work is a function of three modifiers which include ability, level of motivation and role perception. Meanwhile, Sedarmayanti (2004: 177) suggests that several factors that influence job performance are capabilities (ability) and motivation (motivation). This is according to Newstrom and Davis (2002: 15) who formulate that:

- X Knowledge Skill = Ability

- Attitude X Situation = Motivation

- Ability x Motivation = Potential Human Performance

- Potential Human Resource Performance X X Opportunity = Organizational Outcome RESEARCH METHODS

Analysis of the data will be used consist of two types: (1) descriptive analysis especially for qualitative variables, (2) quantitative analysis of testing the hypothesis by using statistical tests. The quantitative analysis emphasized to express the behavior of the research variables, while the descriptive analysis/qualitative used to explore the behavior of the underlying cause. By using a combination of methods of analysis that can be obtained generalization is comprehensive. Based on the methods used in data collection, the ordinal variables that have a size of further transformed into a form of the interval using the Method of Successive Intervals.

Before the data were analyzed, the data processing is done first. Processing of data collected from interviews and questionnaires can be grouped into three steps: preparation, tabulation, and data on the implementation of the research approach. Preparatory research includes activities to collect and check the completeness of the questionnaire and provide value (scoring) by a predetermined grading system. The questionnaire covered using ordinal 
scale 5, the value obtained is an indicator for the pair of independent variables $\mathrm{X}$ and $\mathrm{Y}$ the dependent variable, as follows: $(\mathrm{X}, \mathrm{Y})$ is assumed to be related linearly. Data tabulated results applied to the research approach used by the purpose of research.

The analysis consists of two types: (1) descriptive analysis especially for qualitative variables, (2) quantitative analysis, such as the acquisition of path coefficients and determination stating the influence of independent variables on the dependent variable. The quantitative analysis emphasized to express the behavior of the research variables, while the descriptive analysis/qualitative used to explore the behavior of the underlying cause. The analytical method used in the form of cross-sectional analysis. By using a combination of methods of analysis that can be obtained generalization is comprehensive.

As for the analysis has taken steps as follows: As designed in the operationalization of the variables of the questionnaire, then the value of the variables: workload, competence, and performance are ordinal scale data. By using a type of closed questions (closed-end questions) of each item is determined by the ratings of five alternative answers. The selection of respondents is the score of the answers so that the variable value derived from the total score of the answers of each item. Path analysis techniques require the data requirements that have at least level measurement interval.

\section{RESULTS AND DISCUSSION}

\section{Workload and Competence affect the performance of employees in the Production Department of PT. Pertamina}

Based on the theoretical framework that there is a positive influence between workload and competence on employee performance, the overall hypothesis is:

Table 1. Simultaneous Hypothesis Testing

\begin{tabular}{|c|c|c|c|c|c|c|}
\hline \multicolumn{7}{|c|}{ ANOVA } \\
\hline & Model & Sum of Squares & $d f$ & mean Square & $\mathrm{F}$ & Sig. \\
\hline \multirow{3}{*}{1} & Regression & 104787 & 2 & 52394 & 17255 & $.000 \mathrm{~b}$ \\
\hline & residual & 91092 & 30 & 3,036 & & \\
\hline & Total & 195879 & 32 & & & \\
\hline
\end{tabular}

Based on the results of these calculations in table 1, it turns out Fhitung 17255 greater than ttable 3.23 (Fo> F* (k, nk-1) (17 255> 3.23), so the hypothesis is accepted or H0 is rejected. Means testing of individuals with hypotheses can continue to do that:

\section{Hypothesis Testing Individually}


Table 2 testing Hypothesis

\begin{tabular}{|l|l|l|l|l|}
\hline \multicolumn{2}{|c|}{ coefficient Line } & \multicolumn{1}{c|}{ t } & ttabel & \multicolumn{1}{c|}{ Conclusion } \\
\hline PYX1 & 0133 & 1,194 & 0001 & $\begin{array}{l}\text { Ho rejected } \\
\text { There is the effect of workload on } \\
\text { performance }\end{array}$ \\
\hline PYX2 & 0709 & 4,215 & 0000 & $\begin{array}{l}\text { Ho rejected } \\
\text { There Competence influence on } \\
\text { performance }\end{array}$ \\
\hline
\end{tabular}

Based on the calculation of the value of the path coefficient in table 2, variable (X1) and (X2) to (Y), which is obtained by using the program as SPSS, thus by the rules of the decision, that the prices of $\mathrm{t}$ fall area $\mathrm{H} 0$ is rejected it means the path coefficients significantly so that the path diagram unchanged. The concept can be explained that all aspects of workload and competency aspects affect the performance.

So that Influence the workload and competencies on the performance of employees in the Department of Production PT. Pertamina are:

Table.3. Effect of Variable X1 and X2 to $Y$ and Effect of Excluding variables X and $Y$

\begin{tabular}{|l|c|c|}
\hline \multicolumn{3}{|c|}{ Interpretation Path Analysis } \\
\hline \multicolumn{1}{|c|}{ Information } & Influence & $\%$ \\
\hline Effect of X1, X2 to Y & 0535 & 53.5 \\
\hline Outside influenceX1, X2and Y & 0445 & 52.7 \\
\hline amount & & 100 \\
\hline
\end{tabular}

From the test results it can be seen in table 3, that workload and competence together have an effect on performance, namely $53.5 \%$, while the remaining $44.5 \%$ is influenced by other factors not examined by the author, namely organizational commitment, competence, culture. , a. a leadership style that requires further research. However, if seen partially, competency performance is more dominant than workload. This can be understood as an indicator of workload and competence that is used as an aspect of performance measurement. 
Based on the results of the above calculations, it can be seen that the workload that affects the performance of an employee in the Production Department of PT. Pertamina can be seen in table 4 below:

Table 4 Direct and Indirect Effect Of workload on Performance

\begin{tabular}{|c|l|c|c|}
\hline \multicolumn{4}{|c|}{ Interpretation Path Analysis } \\
\hline Ket & \multicolumn{1}{|c|}{ Influence } & \% \\
\hline X1 & Direct influence to Y & 0.0177 & 1.77 \\
\hline & The indirect effect through X2 to Y & 0.0514 & $5: 14$ \\
\hline amount & & 0.0691 & 6.91 \\
\hline
\end{tabular}

Likewise, the calculation above, it can be revealed that the influence of Competence on employee performance in the Department of Production PT. Pertamina directly or indirectly, can be seen in the table:

Table 5 Direct and Indirect Effect of Competence on performance

\begin{tabular}{|c|l|c|c|}
\hline \multicolumn{4}{|c|}{ Interpretation Path Analysis } \\
\hline Ket & \multicolumn{1}{|c|}{ Influence } & \% \\
\hline X2 & Direct influence to Y & 0.2452 & 24.52 \\
\hline & The indirect effect through X2 to Y & 0.2204 & $22: 04$ \\
\hline amount & & 0.4659 & 46.59 \\
\hline
\end{tabular}

From Table 5, it can be seen that the direct competence contribution to performance is $24.52 \%$, with a coefficient of $4.215 \mathrm{t}$, while for the $\mathrm{t}$ table value at the significance level $\alpha$ $(0.05)=0.00$, because the value of $\mathrm{t}>\mathrm{t}$ table, and indirectly directly through the workload variable of 22: $04 \%$. While the contribution of competence to overall employee performance reaches $46.59 \%$, it can be concluded that competence has a direct effect on performance. The path coefficient shows a positive and significant value, meaning that if competence increases, performance will also increase.

\section{CONCLUSION}

1. [09:09, 9/27/2020] Nandan: 1 . Workload is paramount in any existing institution, both business and non-business. The workload is reflected in the extent to which duties and 
jobs are a major responsibility for employees, in this case it is a burden on the work organization to employees. Workload felt by employees in the Production Department of PT. Pertamina is better able to improve employee performance.

2. Competence to be at the forefront of any existing institution, both business and nonbusiness. Competence reflects the extent to which an employee can multiply the potential that is in it. Competence owned by employees in the Production Department of PT. Pertamina is better able to improve employee performance.

3. Performance is the most important thing in any existing institution, both business and non-business. Performance reflects the extent to which the organization can optimize all capabilities and skills of employees, in this case the employee organization itself. Employee Performance at the Production Department of PT. Pertamina is increasingly able to increase organizational productivity

4. Workload and competence simultaneously influence the performance of employees in the Production Department of PT. Pertamina. But partially Competence is more dominant than Workload Performance. Partially, Workload and Competence affect performance are as follows: Workload affects employee performance, as well as if

a. Workload received is appropriate, the employee performance will also increase.

b. Competence affects employee performance, thus competence accordingly, employee performance will be even higher.

\section{REFERENCE}

AA Anwar King Mangkunegara 2009, Human Resource Management Company, Molds to 3, PT.Remaja Rosda paper, Bandung

Achmad S. Ruky, 2003, the Performance Management System, PT. Gramedia Pustaka Utama, Jakarta.

Arikunto, Suharmini.2003, Management Research, Rineka Cipta, Jakarta.

As'ad, Moh. 2001, Industrial Psychology, Liberty, Yogyakarta. 
A. Usmara, 2002, the New Paradigm for Human Resource Management, Yogyakarta: Book Amara

Bambang Wahyudi, 2002, Human Resource Management, Bandung, CV. Loyal.

Bernardin, John H, and Russell, Joyce EA 2003, Human Resource Management, New York, Mc Graw - Hill Inc.

Bouler, Nick., Murray Dalziel. Jackie Hill. 2001. People and competencies, the Route to Competitive Advantage. Vol 5. New Delhi: Crest Publishing House.

Byars, Lloyd, L and Rue W, Leslie, 2004, Human Resource Management, Int. Edition, McGraw-Hill, Boston.

Clark L, Christopher. 1997 Clarifying The Use Of Competence And Competency Models In Recruitment, Assessment And Staff Development, Industrial And Commercial Training, Vol. 27, No. 11.

Dale, Timpe A, 1998 Series Business Management Science and Art, Performance, Sofyan translation Cikmat, Jakarta, PT Elex Media Computindo.

Keith Davis, New Strom, John W., 2002, in Organization Behavior, Volume I, Erland, Jakarta.

Denton, Robert. 1997, Organizational Planning, Mc. Graw Hill Book Company, New York.

George, Terry R., 2005, Principle Of Management, Seventh Edition, Homewood Illionois, Richsard D. Irwin Inc.

Gomes, Faustino Cardoso. 2003, Human Resource Management, Yogyakarta: Andi Offset.

Grönroos, Erick A, Raymond Zammuto, and Johnson, 1995, The Competing Values Framework Understanding the Impact of Organizational Culture on the Quality of Work Life, Organization Development Journal, Vol. 19, No. 3, 11, pp. 58-68, MCB University Press

T. Hani Handoko, 2004, Personnel Management and Human Resources, BPFE, Yogyakarta.

Harun al-Rashid, 1998, Path Analysis As a Means of Statistics In Causal Analysis, LP3Padjadjaran University, Bandung

Houtzagers, Gijs. 1999 Participation and Empowerment: An International Journal, Vol. 13, No. 4.

Hart, Cathy, et al. 1999 Retailer and Student Perceptions of Competence Development, International Journal of Retail and Distribution Management, Vol. 27, No. 9, pp. 362-373.

Johnson, James L, John M Ivancevich, James H Donnelly Jr. 1995 Organizational Behavior, Structure, Processes, Translation Nunuk Adriani, Binarupa Literacy, Jakarta. 
Mac Lean. 2001 Employee Training and Development. 2nd Edition. New York: The McGraw-Hill Companies, Inc.

Portalhr magazine. No. 08 - in 2004. Competency Magical Recipes.

Throughhttp://www.portalhr.com/majalah/edisisebelumnya/strategi/1id198.html

Mathis, Robert L, and John H.Jackson, 2001, Human Resource Management, 10th Edition, Thomson South-Western, United States.

Milkovich, George T, and Boudreau. 1997. Human Resource Management. Boston: Richard D Irwin Inc

Mitrani, A, Daziel, M. and Fitt, D. 1992, Competence-Based Human Resources Management: Value-Driven Strategies For Recruitment, Development, and Reward. London: Kogan Page Limited.

Nawawi, Usman. 2005, Human Resources, Gunung Agung, Jakarta.

Nguyen, P. T., Yandi, A., \& Mahaputra, M. R. (2020). Factors That Influence Employee Performance: Motivation, Leadership, Environment, Culture Organization, Work Achievement, Competence And Compensation (A Study Of Human Resource Management Literature Studies). Dinasti International Journal of Digital Business Management, 1(4), 645-662.

Nguyen, P. T., Arifani, A. Z. T., Susanti, A. Y., \& Mahaputra, M. R. (2020). LITERETURE REVIEW FACTORS AFFECTING EMPLOYEE PERFORMANCE: COMPETENCE, COMPENSATION AND LEADERSHIP. Dinasti International Journal of Economics, Finance \& Accounting, 1(3), 538-549.

Rianto, Setyo 2004, Effect of Competence and Commitment to Employee Satisfaction and Service Implications Value Kurier., Dissertation., Ubuntu.

Rival, Veithzal \& Fawzi, Ahmad. 2005. Performance Appraisal System Right To Assess Employee Performance and Improving the Competitiveness of the Company. PT. King Grafindo Persada. Jakarta

Robbins, S. 2003 Organizational Behavior, 9th Edition, Prentice Hall International, Inc., New Jersey

Schuler, Randall, and Susan E.Jackson, 2002, Human Resource Management, Positioning for the 21 st Century, 6th Edition, West Publishing, Co., New York.

Uma has now. 2000 Research Methods for Business, Third Edition, John Wiley \& Sons, Inc., New York.

Sedarmayanti 2004, Human Resources and Labor Productivity, Bandung: Mizan.

Sondra P. Siagian, 2008, the Administrative Philosophy, Jakarta, PT. Holy mountain 
Spencer, M.Lyle and Spencer, M.Signe. 1993. Competence at Work: Models for Superior.

Sinungan, 1986, Organizational Behavior, University of Padjadjaran Bandung.

Su'ad, Husnan, and Heidjrachman, 1990, Performance Assessment and Employee Development, BPFE, Yogyakarta.

Sugiyono 2006, Business Research Methods, Bandung Alfabeta.

Sumantri Suryana, 2001, Organizational Behavior, University of Padjadjaran Bandung

Supriyanto, Budi. 2009. Government Management (Plus Twelve-Step Strategic). Tangerang: Cv. Brilliant Media.

Winardi. 2000. Motivation and motivating in Management. Jakarta: PT, King Grafindo Persada.

Wood, Wallace, and Zeffane, 1998, Organization Behavior in Asia Pacific Perspective, New York, John Wiley and Sons

Yuyun Wirasasmita. 2004. Some Notes Use Path Analysis In Writing Thesis and Dissertation. Paper Materials II Semester Graduate Program UNPAD.

Law No. 8 of 1981, oversight of the Civil Servant Investigators (investigators)

Law No. 2 of 2002 supervision of the Civil Servant Investigators (investigators) 